\title{
Chromobacteriosis (Chromobacterium violaceum) in a calf from Brazil - case report
}

\author{
R.L. Soares ${ }^{1}$, N.B. Dias Neto ${ }^{1}$, C.C. Guizelini ${ }^{1}$, M.A. Araújo $^{2}$, \\ C.R.B. Leal ${ }^{2}$, T.B.M. Möck ${ }^{2}$, C.A.N. Ramos ${ }^{2}$ \\ ${ }^{1}$ Residente - Universidade Federal de Mato Grosso do Sul - Campo Grande, MS \\ ${ }^{2}$ Universidade Federal de Mato Grosso do Sul - Campo Grande, MS
}

\begin{abstract}
Chromobacterium violaceum is a rare opportunistic pathogen that causes highly fatal infections in domestic animals and humans. This report describes a fatal case suggestive of septicemia in a four-dayold female calf with chromobacteriosis. The calf had suppurative omphalophlebitis, suppurative fibrinous polyarthritis, anterior uveitis with bilateral fibrin deposition, fibrinous peritonitis, lymph node abscess and multifocal lymphocytic and neutrophilic encephalitis with multifocal hemorrhages. C. violaceum was isolated from the spleen and peri-renal lymph node and its identity was confirmed by PCR and sequencing. The pathogen was sensitive to azithromycin, gentamicin, enrofloxacin, norfloxacin, marbofloxacin, ciprofloxacin, erythromycin, sulphazotrim, fluorfenicol, tetracycline and doxycycline as well as resistant to penicillin, ampicillin, vancomycin, amoxicillin, amoxicillin + clavulanic acid, cephalothin, cephalexin, oxacillin, B polymyxin, neomycin and bacitracin. This is the first report of chromobacteriosis in a calf from Brazil.
\end{abstract}

Keywords: $C$. violaceum, cattle, Brazil

\section{RESUMO}

Chromobacterium violaceum é um patógeno oportunista raro, que causa infecção fatal em animais domésticos e em humanos. Este relato descreve um caso fatal suspeito de septicemia em um bezerro de quatro dias, fêmea, infectado por C. violaceum. O bezerro apresentava onfaloflebite supurativa, poliartrite supurativa fibrinosa, uveíte anterior com deposição bilateral de fibrina, peritonite fibrinosa, abscesso de linfonodos e encefalite multifocal linfocítica e neutrofílica com áreas hemorrágicas multifocais. C. violaceum foi isolado no baço e no linfonodo, e sua identidade foi confirmada por PCR $e$ sequenciamento. O patógeno foi sensível aos antibióticos azitromicina, gentamicina, enrofloxacina, norfloxacina, marbofloxacina, ciprofloxacina, eritromicina, sulfazotrim, florfenicol, tetraciclina, doxiciclina e foi resistente à penicilina, ampicilina, vancomicina, amoxicilina, amoxicilina + ácido clavulânico, cefalotina, cefalexina, oxacilina, polimixina $B$, neomicina e bacitracina. Este é o primeiro relato de cromobacteriose em bezerro no Brasil.

Palavras-chave: C. violaceum, bovino, Brasil

\section{INTRODUCTION}

Chromobacterium violaceum is a saprophytic Gram-negative bacillus that grows on MacConkey agar and produces a violet pigment called violacein (Richard, 1993). It is found in soil and water in tropical and subtropical regions

Recebido em 5 de outubro de 2018

Aceito em 9 de abril de 2019

E-mail: rodrigo_fls@hotmail.com and has been recognized as an opportunistic pathogen of humans and animals (Richard, 1993). In humans, C. violaceum infection can cause abscesses in skin and visceral organs, such as the liver, lungs, kidneys, spleen and lymph nodes, and can cause septicemia with necrotizing lesions in multiple organs, resulting in death (Siqueira et al., 2005; Teoh et al., 2006). 
Although highly fatal, infections by $C$. violaceum are rarely reported in animals (Carrasco et al., 1996; Ajithdoss et al., 2009). In domestic animals, visceral abscesses, pleuropneumonia and septicemia have been reported in a pig (Liu et al., 1989), sheep (Carrasco et al., 1996), dogs (Crosse et al., 2006) cattle (Ajithdoss et al., 2009) and a horse (Hammerschmitt et al., 2017). This report describes a fatal case suggestive of septicemia associated with Chromobacterium violaceum in a calf from the central western region of Brazil.

\section{CASE REPORT}

A four-day-old Nelore female was taken to the Veterinary Teaching Hospital of the Universidade Federal do Mato Grosso do Sul with the complaint of apathy, recumbency and blindness. The owner reported that the animal had been abandoned by the mother after birth and had not suckled, but had been fed milk from a bottle. The physical examination revealed a low level of consciousness, sternal decubitus, weakness, cachexia, capillary perfusion time of three seconds, dehydration $(10 \%)$, congested oculopalpebral and buccal mucosa, anterior uveitis with bilateral hypopyon (Figure 1), absent visual threat reflex, brachygnathism, flexor deformity of the right metacarpophalangeal joint, multiple swelled joints, polyarthritis, enlarged navel draining purulent secretion, rectal temperature of $38.5^{\circ} \mathrm{C}$, heart rate of $90 \mathrm{bpm}$ with arrhythmia, respiratory rate of $20 \mathrm{mpm}$ and dyspnea. The hematological analysis revealed hypoglobulinemia, lymphopenia, neutrophilia and monocytosis. The owners declined to treat the animal and it was euthanized according to current regulations.

At necropsy, all joints of the thoracic and pelvic limbs were enlarged and some exhibited pus intermingled with the synovial fluid. Approximately $100 \mathrm{~mL}$ of clear, translucent, free liquid was found in the abdominal cavity, mixed with rare small flakes of fibrin. The iliac and peri-renal lymph nodes were enlarged and the latter expressed pus when cut. Fibrin was found in both anterior chambers. Tissue samples from organs were fixed in a $10 \%$ formalin solution, routinely processed and stained with hematoxylin and eosin for the histopathological analysis. Samples of the spleen, liver, kidney and peri-renal lymph node were submitted to bacterial cultures.

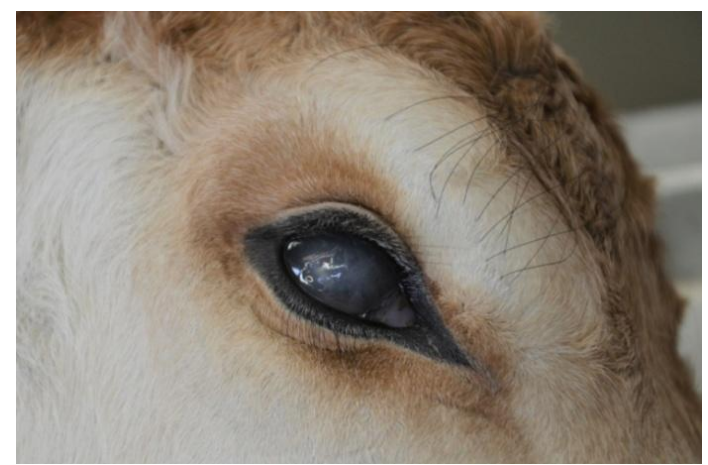

Figure 1. Anterior uveitis with hypopyon in calf infected with Chromobacterium violaceum.

Microscopically, the hepatic sinusoids contained neutrophils and the hepatic capsule was covered with fibrin and few macrophages. Hepatocytes and epithelial cells of renal tubules contained hemosiderin. The peri-renal lymph node was expanded by an abscess, which was an organized mass of degenerate neutrophils surrounded by layers of fibrin that obliterated the nodal architecture. In the medullary and subcapsular sinuses of the internal iliac lymph node, large numbers of neutrophils and macrophages were found with vacuolated cytoplasm and little hemosiderin. Clusters of basophilic structures (bacteria) mixed with intact and degenerate neutrophils obliterated the lumen of the umbilical veins. In the frontal cortex, thalamus and obex, small focal points of neutrophils and lymphocytes were found around a vessel (perivascular cuff).

Samples from the liver, kidney, spleen and perirenal lymph node were inoculated on blood agar (supplemented with 5\% defibrinated ovine blood), brain heart infusion (BHI) agar and MacConkey agar. The cultures were incubated at $37^{\circ} \mathrm{C}$ under aerobic conditions for 48 hours. After 24 hours of incubation, pure cultures of dark purple colonies typical of Chromobacterium violaceum were found in the spleen and perirenal lymph node samples (Figure 2). The colonies were characterized as a Gram-negative bacillus, catalase-positive, oxidase positive, glucose fermenter without gas. A set of biochemical tests was also performed, the results of which are displayed in Table 1. 


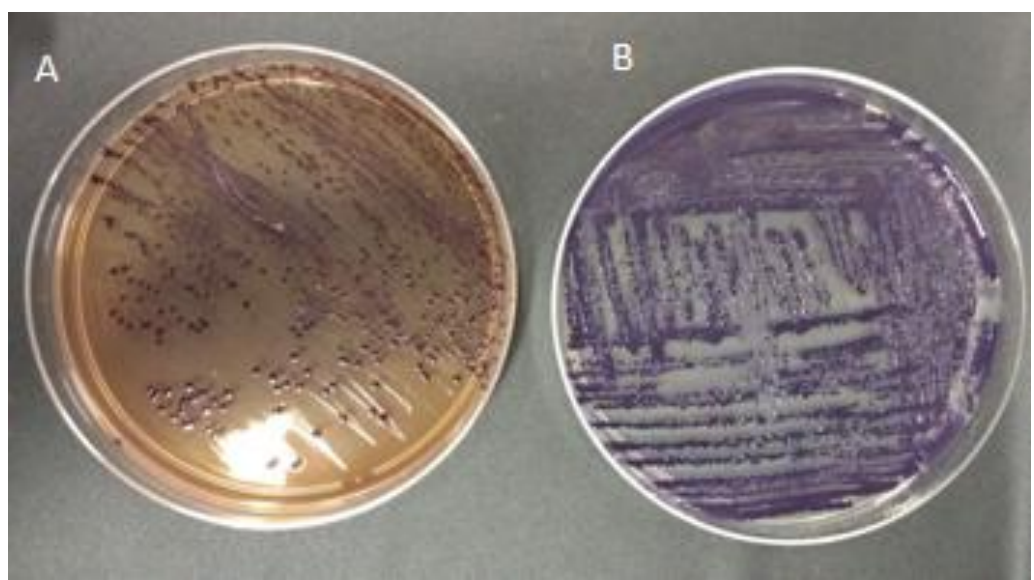

Figure 2. Chromobacterium violaceum in MacConkey (A) and BHI (B) agar dishes after 24 hours of incubation.

Table 1. Biochemical characteristics of Chromobacterium violaceum isolated from spleen and peri- renal lymph node in calf

\begin{tabular}{lc}
\hline Test & Results \\
\hline Gram-staining & - \\
Growth on MacConkey agar & + \\
Lactose & - \\
Catalase & + \\
Oxidase & - \\
B-hemolysis & + \\
Motility & + \\
Indole production & - \\
Growth on TSI agar & + \\
Glucose & + \\
Gas glucose & - \\
H2S production & - \\
Citrate & - \\
Urease production & - \\
\hline - negative; + positive &
\end{tabular}

The in vitro antimicrobial susceptibility test was performed using the disk diffusion technique in Mueller Hinton agar. The isolated $C$. violaceum was sensitive to azithromycin $(15 \mu \mathrm{g})$, gentamicin $(10 \mu \mathrm{g})$, enrofloxacin $(5 \mu \mathrm{g})$, norfloxacin $(10 \mu \mathrm{g})$, marbofloxacin $(5 \mu \mathrm{g})$, ciprofloxacin $(5 \mu \mathrm{g})$, erythromycin $(15 \mu \mathrm{g}), \quad$ sulphazotrim $(25 \mu \mathrm{g})$ fluorfenicol $(30 \mu \mathrm{g})$, tetracycline $(30 \mu \mathrm{g})$ and doxycycline $(30 \mu \mathrm{g})$. The pathogen was resistant to penicillin (10IU), ampicillin $(10 \mu \mathrm{g})$, vancomycin $(30 \mu \mathrm{g}), \quad$ amoxicillin $(10 \mu \mathrm{g})$, amoxicillin + clavulanic acid $(30 \mu \mathrm{g})$, cephalothin $(30 \mu \mathrm{g})$, cephalexin $(30 \mu \mathrm{g})$, oxacillin $(1 \mu \mathrm{g}), \mathrm{B}$ polymyxin $(300 \mu \mathrm{g})$, neomycin $(30 \mu \mathrm{g})$ and bacitracin (10IU).
For molecular analysis, a colony of isolated $C$. violaceum was inoculated in a micro tube with BHI broth $(1.0 \mathrm{~mL})$ and incubated for 48 hours at $37^{\circ} \mathrm{C}$. The micro tube was then centrifuged at $10,000 \mathrm{xg}$ for five minutes, and the supernatant discarded. The sediment was suspended in $500 \mu \mathrm{L}$ sodium dodecyl sulfate $20 \%$ (SDS), from there the extraction of DNA followed established protocol according to Araújo et al. (2009). The quantity and integrity of the extracted DNA were verified by spectrophotometry (A260/A280) (BioPhotometer Plus, Eppendorf) and $1 \%$ agarose gel electrophoresis, respectively.

Detection of the $16 \mathrm{~S}$ rRNA gene of $C$. violaceum was performed using the polymerase chain reaction (PCR) according to Kazemiha et al. (2009). The amplification products were viewed under ultra violet light after electrophoresis on agarose gel (1.5\%) stained with GelRed (Biotium) according to manufacturer's instructions. Base pair ladder of 100bp (Ludwig Biotec) were used for measurement of amplified fragments.

The amplicon (approximately 420bp) was purified using ExoSAP-IT Express (Applied Biosystems) in accordance with manufacturer's instructions. The sample was sequenced in both directions using an automated sequencer ABI 3130 (Applied Biosystems). The chromatograms were evaluated and edited using Contig editor program (Gene Studio) v. 2.2.0, and the consensus sequence (306bp) was submitted to BLASTn analysis, in order to determine the sequence indentity by comparison with sequences available in the GenBank database. 
Through DNA sequence analysis of 16S rRNA gene, it was possible to identify the species Chromobacterium violaceum (identity of $99 \%$ ). The DNA sequence obtained in the present study was deposited in the Genbank database under the accession number MH899593.

\section{DISCUSSION}

Reports of chromobacteriosis are rare in Brazil. However, some cases have been described in humans, which resulted in highly fatal infections (Siqueira et al., 2005). Reports worldwide have been associated with rural areas or stagnant water (Siqueira et al., 2005), but there are few reports in domestic animals (Liu et al., 1989; Carrasco et al., 1996; Crosse et al., 2006; Ajithdoss et al., 2009; Hammerschmitt et al., 2017). In Brazil, only a recent report in a horse has been published (Hammerschmitt et al., 2017). Therefore, to the best of our knowledge, this is second animal case in Brazil and the first report of $C$. violaceum infecting cattle in the country.

Infection can occur orally, through injured skin's contact with contaminated water or soil (Richard, 1993; Siqueira et al., 2005; Crosse et al., 2006), and by airways (Siqueira et al., 2005; Hammerschmitt et al., 2017). However, the clinical course and some lesions found, like necrosuppurative omphalophlebitis, indicate that the umbilicus was the likely point of entry in the present report, similar to findings described in a calf with chromobacteriosis reported by Ajithdoss et al. (2009). Most human cases of chromobacteriosis have occurred in children and immunosuppressed patients (Siqueira et al., 2005; Teoh et al., 2006). In animals, Hammerschmitt et al. (2017) suggest that the immaturity or suppression of the immune system may be a predisposing factor to infection and development of the disease. In the present report, the calf have had a passive immunity failure by not ingesting the colostrum due a flexor deformity of the metacarpophalangeal joint, which led to hypoglobulinemia, thereby predisposing the calf to infection.

In humans, $C$. violaceum infection can cause abscesses in skin and visceral organs, such as the liver, lungs, kidneys, spleen, lymph nodes and brain, which can rapidly disseminate and cause fulminating septicemia, with necrotizing lesions in multiple organs and death (Siqueira et al., 2005; Teoh et al., 2006). Some clinical and pathological conditions in domestic animals are similar. Reports in animals include suppurative pneumonia, abscesses and necrosis in the lungs and liver (Liu et al., 1989; Ajithdoss et al., 2009; Hammerschmitt et al., 2017), splenitis (Carrasco et al., 1996; Ajithdoss et al., 2009), meningoencephalitis (Liu et al., 1989; Ajithdoss et al., 2009), necrosuppurative omphalophlebitis, anterior uveitis with hypopyon, suppurative polyarthritis (Ajithdoss et al., 2009) and fibrinous pericarditis (Carrasco et al., 1996; Crosse et al., 2006). The clinical signs reported in the present study are consistent with those previously described in animals. Moreover, the histological lesions, although non-specific, are similar to those observed by Ajithdoss et al. (2009).

The diagnosis of $C$. violaceum infection in animals and humans is usually based on cultures of blood samples, tissues, exudates and abscesses, with easy growth in blood agar, chocolate agar and MacConkey agar (Siqueira et al., 2005; Teoh et al., 2006; Ajithdoss et al., 2009; Hammerschmitt et al., 2017). In the present report, BHI was also successfully used to isolate the pathogen. Although there is no difficulty in isolating this agent from postmortem and clinical samples, according to Ajithdoss et al. (2009), C. violaceum infections may be under-diagnosed for several reasons, such as the fact that acute death often precludes the antemortem diagnosis and animals dying with obvious lesions of septicemia may not be cultured. Since $C$. violaceum is a common saprophyte found in water and soil, its isolation from animals at necropsy may be interpreted as a contaminant. Moreover, polymicrobial infections, which are frequently found in septicemic calves, may further confound the accurate diagnosis of chromobacteriosis. In the present report, the diagnosis was based on the positive isolation of this single bacterium from the spleen and peri- renal lymph node as well as the acute onset and clinical course of disease in a neonate.

The multi-drug resistant nature of $C$. violaceum has also been reported worldwide in mammals (Carrasco et al., 1996; Siqueira et al., 2005; Teoh et al., 2006; Ajithdoss et al., 2009; Hammerschmitt et al., 2017), with resistance 
mainly to penicillins and cephalosporins (Teoh et al., 2006), which was also found in the present case. This may be associated with the occurrence of multiple drug resistant genes, such as betalactam antibiotic resistance genes and drug efflux pump genes (Fantinatti-Garboggini et al., 2004). When these resistance genes are associated with multiple potential virulence factors, such as type IV pili, lipopolysaccharide and hemolysin, which have been identified in the $C$. violaceum genome (Brito et al., 2004), chromobacteriosis in mammals usually results in highly fatal infection with acute progression, characteristic of septicemia and causing death when not diagnosed and treated early. Fluorquinolone and carbapenem are normally very effective and recommended for humans (Siqueira et al., 2005; Teoh et al., 2006). For animals, fluorquinolone, tetracycline and gentamicin have shown efficacy (Carrasco et al., 1996; Crosse et al., 2006), as also observed in the present report.

\section{CONCLUSIONS}

This report represents the first description of $C$. violaceum infecting a calf in Brazil. The infection was likely related to a lack of umbilical antisepsis and passive immunity failure.

\section{ACKNOWLEDGMENT}

This study was financed in part by the Coordenação de Aperfeiçoamento de Pessoal de Nível Superior - Brasil (CAPES) - Finance Code 001

\section{REFERENCES}

AJITHDOSS, D.K.; PORTER, B.F.; CALISE, D.V. et al. Septicemia in a neonatal calf associated with Chromobacterium violaceum. Vet. Pathol., v.46, p.71-74, 2009.

ARAUJO, F.R.; RAMOS, C.A.N.; LUIZ, H.L. et al. Avaliação de um protocolo de extração de DNA genômico a partir de sangue total. Campo Grande: Embrapa Gado de Corte2009. p.120. (Comunicado Técnico, n.5).
BRITO, C.F.; CARVALHO, C.B.; SANTOS, F. et al. Chromobacterium violaceum genome: molecular mechanisms associated with pathogenicity. Genet. Mol. Res., v.3, p.148-161, 2004.

CARRASCO, L.; ASTORGA, R.; MENDEZ, A. et al. Acute pleuropneumonia in Barbary sheep (Amnotragus lervia) associated with Chromobacterium violaceum. Vet. Rec., v.138, p.499-500, 1996.

CROSSE, P.A.; SOARES, K.; WHEELER, J.L. et al. Chromobacterium violaceum infection in two dogs. J. Am. Anim. Hosp. Assoc., v.42, p.154-159, 2006.

FANTINATTI-GARBOGGINI, F.; ALMEIDA, R.; PORTILLO, V.A.; BARBOSA, T.A. et al. Drug resistance in Chromobacterium violaceum. Genet. Mol. Res., v.3, p.134-147, 2004.

HAMMERSCHMITT, M.E.; ROLIM, V.M.; SNEL, G.G.M. Chromobacterium violaceum infection in a horse. J. Comp. Pathol., v.156, p.334-338, 2017.

KAZEMIHA, V.M.; SHOKRGOZAR, M.A.; ARABESTANI, M.R. et al. PCR-based detection and eradication of mycoplasmal infections from various mammalian cell lines: a local experience. Cytotechnology, v.61, p.117-124, 2009.

LIU, C.H.; CHU, R.M.; WENG, C.N. et al. An acute pleuropneumonia in a pig caused by Chromobacterium violaceum. J. Comp. Pathol., v.100, p.459-463, 1989.

RICHARD, C. Chromobacterium violaceum, opportunist pathogenic bacteria in tropical and subtropical regions. Bull. Soc. Pathol. Exot., v.86, p.169-173, 1993.

SIQUEIRA, I.C. et al. Chromobacterium violaceum in siblings, Brazil. Emerg. Infect. Dis, v.11, p.1443-1445, 2005.

TEOH, A.Y.; HUI, M.; NGO, K.Y. et al. Fatal septicaemia from Chromobacterium violaceum: case reports and review of the literature. Hong Kong Med. J., v.12, p.228-231, 2006. 